\title{
Editorial
}

\section{Multiple Sclerosis in Latin America}

\author{
Teresa Corona $^{a}$ Gustavo C. Román ${ }^{b}$ \\ ${ }^{a}$ National Institute of Neurology and Neurosurgery, Mexico City, Mexico; ${ }^{b}$ University of Texas Health Science \\ Center at San Antonio, San Antonio, Tex., USA
}

\section{Key Words}

Multiple sclerosis, geographic distribution · Latin America

\section{Introduction}

The epidemiology of multiple sclerosis (MS) has been thoroughly studied in developed countries, particularly in areas traditionally known for their high prevalence. However, there is a dearth of epidemiological information on MS from large areas of the world. It is generally accepted that MS incidence and prevalence are higher in latitudes north and south of the Equator with prevalences ranging from 80 to $300 / 100,000$. In contrast, its prevalence in Africa, Asia and South America has been estimated around 5/100,000 [1, 2]. However, lack of adjustment of crude incidence and prevalence rates to a common standard population creates problems in the comparison and interpretation of geographic data [3]. Nonetheless, recent studies indicate an increasing risk of developing MS over time in areas such as Sardinia [4], Norway [5], and Sweden [6], as well as in countries previously considered to have low MS prevalence such as Mexico [7].

\section{MS in Latin America}

During the last decade, there has been a surge of research interest on the epidemiology of MS in Latin America. Despite some methodological shortcomings, recently published epidemiological studies begin to provide a reasonable estimate of the frequency and characteristics of MS in Latin America.

In Mexico, hospital-based and population-based studies indicate an increase in the incidence and prevalence of MS. In 1970, Alter and Olivares [8] reported a relatively low prevalence of $1.6 / 100,000$. This study was not confirmed by community-based data. More recent studies based on referrals to a tertiary neurological center demonstrate an important increase in MS incidence [911]. A study in northern Mexico ( $25^{\circ}$ north) found a prevalence of 13/100,000 inhabitants [9]. However, this study included only patients with social security benefits, representing $51 \%$ of the population. Other studies performed in central areas of the country have registered lower prevalences of about $5 / 100,000$ at latitudes $16-20^{\circ}$ north [10]. Clearly, MS has become one of the main causes of neurological consultation in Mexico. For instance, optic neuritis represents $12 \%$ of the patients referred to a specialized neuro-ophthalmology clinic [12]; about $40 \%$ of them are eventually diagnosed as having MS [12, 13]. Potential risk factors responsible for the increase in MS in Mexico include a decrease in breastfeeding for large segments of the society and an increased incidence of varicella and childhood eczema [14]. Research conducted at the National Institute of Neurology and Neurosurgery of Mexico has demonstrated activation of varicella-zoster virus during MS relapses [15], suggesting that this herpes virus could be an etiological agent of MS.

In 1999, the Latin American Committee for Treatment and Research in MS (LACTRIMS) was formally organized generating renewed interest in numerous coun-

\section{KARGER \\ Fax +41613061234 E-Mail karger@karger.ch} www.karger.com
(C) 2006 S. Karger AG, Basel 0251-5350/06/0261-0001\$23.50/0

Accessible online at: www.karger.com/ned
Teresa Corona, MD

National Institute of Neurology and Neurosurgery

Insurgentes Sur 3877

La Fama, 14269 México D.F. (Mexico)

Tel./Fax +525 556064532, E-Mail coronav@servidor.unam.mx 
tries [16, 17]. In Argentina, Cristiano et al. [18], using a capture-recapture method, reported a prevalence of MS of $12 / 100,000$, indicating a low-intermediate risk. However, prevalences as high as $88 / 100,000$ have been reported [19]. Studies from Brazil show variable prevalences within the country $[20,21]$, perhaps due to their ethnic heterogeneity. In Sao Paulo (23-24 south), Callegaro et al. [22] found a prevalence of $15 / 100,000$. In Uruguay, Ketzoian et al. [23] found in a capture-recapture study a prevalence of 20.9/100,000. In Colombia, MS prevalence shows geographic variations ranging from 1.48 to 4.98/100,000 [24]. Genetic studies in Medellin demonstrated in this population that HLA DQAI polymorphisms at chromosome $6 \mathrm{p} 21.3-21.4$ were associated with a high or low predisposition to suffer from MS $[25,26]$. Of interest, MS in this genetically homogeneous population presented clinically with a preponderance of optic neuritis and motor symptoms in the absence of cerebellar manifestations [27]. This pattern is significantly different from that observed at onset in temperate regions. In
Chile, MS corresponds to $3.4 \%$ of hospitalized patients in the city of Santiago [28]; a recent study reported a prevalence of $11.7 / 100,000$ [29].

In the Caribbean, a few studies have reported case series from Puerto Rico [30] and Cuba [31], but prevalence data appear unreliable. The presence of epidemic optic myeloneuropathy in Cuba [32], and tropical spastic paraparesis from HTLV-I infections of the nervous system [33] in the Caribbean, constitutes complicating factors for prevalence studies of MS in this region.

In conclusion, there is growing epidemiological evidence indicating an increased prevalence of MS in areas previously considered as low risk in Latin America. It should be mentioned that the social and economic conditions in Latin America often exclude patients with bona fide MS from adequate treatment. It is hoped that future studies on the natural history, genetics and environmental factors at play in these populations will contribute to elucidate the etiology and pathogenesis of MS.

\section{References}

1 Poser CM: An atlas of multiple sclerosis; in Poser CM (ed): Multiple Sclerosis. New York, Parthenon Publishing Group, 1998.

$\checkmark 2$ Kurtzke JF: Epidemiology and etiology of multiple sclerosis. Phys Med Rehabil Clin North Am 2005; 16:327-349.

$\checkmark 3$ Zivadinov R, Iona L, Monti-Bragadin L, Bosco A, Jurjevic A, Taus C, Cazzato G, Zorzon M: The use of standardized incidence and prevalence rates in epidemiological studies on multiple sclerosis: a meta-analysis study. Neuroepidemiology 2003;22:65-74.

-4 Pugliatti M, Riise T, Sotgiu MA, Sotgiu S, Satta WM, Mannu L, Sanna G, Rosati G: Increasing incidence of multiple sclerosis in the province of Sassari, northern Sardinia. Neuroepidemiology 2005;25:129-134.

$\checkmark 5$ Dahl OP, Aarseth JH, Myhr KM, Nyland H, Midgard R: Multiple sclerosis in Nord-Trondelag County, Norway: a prevalence and incidence study. Acta Neurol Scand 2004; 109: 378-384.

-6 Sundström P, Nyström L, Forsgren L: Incidence (1988-1997) and prevalence (1997) of multiple sclerosis in Vasterbotten County in northern Sweden. J Neurol Neurosurg Psychiatry 2003;74:29-32.

7 González O, Sotelo J: Is the frequency of multiple sclerosis increasing in México? J Neurol Neurosurg Psychiatry 1995;59:528-530.

$>8$ Alter M, Olivares O: Multiple sclerosis in México. Arch Neurol 1970:23; 451-459.
9 Velázquez M, Macias MA, Rivera OV, Lozano Z: Grupo Mexicano de estudio de la esclerosis múltiple. Rev Neurol 2003;36:1019-1022.

10 Corona T, Rodríguez LJ, Otero E, Stopp L: Multiple sclerosis in México: hospital cases at the National Institute of Neurology and Neurosurgery. Neurología 1996;11:170-173.

11 Aguilar F, Estañol B, Del Angel A, Cabañas A, López G, Benitéz L: Esclerosis múltiple: estudio clínico, paraclínico y manejo de 24 casos. Rev Invest Clin 1985;37:231-235.

12 Corona T, Ruiz JL, Arriada N: Optic neuritis progressing to multiple sclerosis. Acta Neurol Scand 1997;95; 85-89.

13 Lazo M, Corona T: Neuritis óptica: seguimiento a largo plazo en población mexicana. Rev Neurol 2002;35:1190.

14 Tartas R, Ordoñez G, Rios C, Sotelo J: Varicella, ephemeral breastfeeding and eczema as risk factors for multiple sclerosis in Mexicans. Acta Neurol Scand 2002; 105:88-94.

15 Ordoñez G, Pineda B, Garcia-Navarrete R, Sotelo J: Brief presence of varicella-zoster viral DNA in mononuclear cells during relapses of multiple sclerosis. Arch Neurol 2004;61:529_ 532.

16 Rivera VM, Cabrera JA: Avance de la esclerosis múltiple en Latinoamérica. Médico Interam 2000;19:458-465.
17 Rivera VM: Simposio de esclerosis multiple en Houston: introducción. Rev Neurol 2003;31: 469.

18 Cristiano E, Patrucco L, Garcea O, Carra A, Cáceres F, Krementchutsky M, et al: Prevalence of multiple sclerosis (MS) in Argentina using the capture-recapture method. Neurology 1999;2(suppl):A438.

19 Piedrabuena R, Giobellina R, Alvarez D, Abatedaga V: High prevalence of multiple sclerosis in the city of Oliva, Cordoba, Argentina. Arq Neuropsiquiatr 2004;62:13.

20 Papais-Alvarenga R, Alves S, Miranda C, Tilbery $\mathrm{C}$, Poser CM, Alvarenga $\mathrm{H}$, et al: Characteristics of multiple sclerosis in Brazil: multicentric study in a prevalence cohort - South Atlantic project phase 1. J Neurol Sci 1997; 150:S229.

21 Gama P, Trigo L, Andrade R, Sala C: On behalf of the Brazilian Committee for Treatment and Research in Multiple Sclerosis (BCTRIMS): epidemiological study of multiple sclerosis in the city of Sorocaba, Brazil. Arq Neuropsiquiatr 2004;62:13.

22 Callegaro D, Godbaum M, Morais L, Tilbery CP, Moreira MA, Gabbai AA, Scaff M: The prevalence of multiple sclerosis in the city of Sao Paulo, Brazil. Acta Neurol Scand 2001: 104:2208-2137.

23 Ketzoian C, Oeninger C, Alcántaran J, et al: Estudio de la prevalencia de la esclerosis múltiple en Uruguay. Acta Neurol Col 1999;15:6. 
-24 Sánchez JL, Aguirre C, Arcos OM, Jiménez I, Jiménez M, León F, et. al: Prevalencia de la esclerosis múltiple en Colombia. Rev Neurol 2000;31:1101-1103.

-25 Palacio LG, Rivera D, Builes JJ, Jiménez ME, Salgar M, Anaya JM, Jiménez I, Camargo M, Arcos-Burgos M, Sánchez JL: Multiple sclerosis in the tropics: genetic association to STR's loci spanning the HLA and TNF. Mult Scler 2002;8:249-255.

-26 Arcos-Burgos M, Palacio G, Sánchez JL, Londoño AC, Uribe CS, Jiménez M, Villa A, Anaya JM, Bravo ML, Jaramillo N, Espinal C, Builes JJ, Moreno M, Jiménez I: Multiple sclerosis: association to HLA DQ $\alpha$ in a tropical population. Exp Clin Immunogenet 1999;16: 131-138.
27 Sánchez JL, Palacio LG, Uribe CS, Londoño AC, Villa A, Jiménez M, Anaya JM, Jiménez I, Camargo M, Arcos-Burgos M: Clinical features of multiple sclerosis in a genetically homogeneous tropical population. Mult Scler 2001;7:227-229.

28 Alvarez G, Castillo J, Cárdenas M, Fauré E, Ruíz F, Lavados J: Multiple sclerosis in Chile. Acta Neurol Scand 1992;85:1-4.

29 Barahona J, Montero A, Flores A: Multiple sclerosis in Chile. Arq Neuropsiquiatr 2004: 62:11.
30 Sánchez LP, Fiol M, Cedó P: Multiple sclerosis in Puerto Rico (experience at the university hospital): review of a series of cases. Bol Asoc Med P Rico 1972;64:176-178.

31 Cabrera-Gómez JA, López O: Morbilidad por enfermedades neurológicas en el Servicio de Neurología: estudio de un quinquenio. Rev Cubana Med 1990;29:161-172.

32 Román GC: An epidemic in Cuba of optic neuropathy, sensorineural deafness, peripheral sensory neuropathy and dorsolateral myeloneuropathy. J Neurol Sci 1994;127:11-28.

33 Román GC, Vernant J-C, Osame M (eds): HTLV-I and the Nervous System. New York, Liss, 1989. 